\title{
Barbara Brend, Charles Melville (eds.). Epic of the Persian Kings. The Art of Ferdowsi's Shahnameh
}

\section{Ève Feuillebois-Piérunek}

\section{(2) OpenEdition \\ 12 Journals}

\section{Édition électronique}

URL : http://journals.openedition.org/abstractairanica/40945

DOI : 10.4000/abstractairanica.40945

ISSN : 1961-960X

Éditeur :

CNRS (UMR 7528 Mondes iraniens et indiens), Éditions de l'IFRI

\section{Édition imprimée}

Date de publication : 1 décembre 2013

ISSN : 0240-8910

\section{Référence électronique}

Ėve Feuillebois-Piérunek, « Barbara Brend, Charles Melville (eds.). Epic of the Persian Kings. The Art of Ferdowsi's Shahnameh », Abstracta Iranica [En ligne], Volume 32-33 | 2013, document 419, mis en ligne le 01 juillet 2016, consulté le 03 octobre 2020. URL : http://journals.openedition.org/abstractairanica/ 40945 ; DOI : https://doi.org/10.4000/abstractairanica.40945

Ce document a été généré automatiquement le 3 octobre 2020.

Tous droits réservés 


\title{
Barbara Brend, Charles Melville (eds.). Epic of the Persian Kings. The Art of Ferdowsi's Shahnameh
}

\author{
Ève Feuillebois-Piérunek
}

\section{RÉFÉRENCE}

Barbara Brend, Charles Melville (eds.). Epic of the Persian Kings. The Art of Ferdowsi's

Shahnameh. London/New York, I. B. Tauris, 2010, 270 p.

1 Ce très beau livre a été publié dans le cadre de l'exposition du même nom au Fitzwilliam Museum de Cambridge à l'initiative de Charles Melville qui a confié la majeure partie du travail à une chercheuse indépendante, Barbara Brend.

2 L'ouvrage débute par une série d'essais introductifs. Le premier, intitulé The Shahnameh in Historical Context, de la plume de Melville, consiste en une présentation classique de ce chef-d'œuvre. L'A. s'intéresse en particulier à l'usage qu'en ont fait les grandes dynasties ilkhanide, safavide, moghole. Le second essai, rédigé par F. Abdullaeva, s'intitule The Shahnameh in Persian Literary History: il y est question de la poésie avant Ferdowsī, des précurseurs de l'épopée, de sa réception, des suites qui ont été rédigées après la mort de l'auteur. Le troisième essai, The Shahnameh as World Literature, de Dick Davis, donne un aperçu du contenu du Livre des Rois. La quatrième, The Tradition of Illustration, de B. Brend présente la tradition d'illustration des manuscrits, ses grandes périodes et caractéristiques.

3 La partie principale du livre, The Shahnameh in Art, rassemble 104 illustrations choisies et commentées par B. Brend (sources, explication des éléments-clés, bibliographie). Les images sont classées chronologiquement en cinq parties : 'The Shape of The Shahnameh' ; 'An Explosion of Images, 12th-14th c.' ; 'Princely Patronage and Beyond, the 15th c.' ; 'Old and New Ways of Seeing, the 16-19th c.' ; 'The Shahnameh in India, the 15th-19th c.'. 
4 L'ouvrage se termine sur une liste des personnages du Livre des Rois, un glossaire, la liste des manuscrits illustrés et folios dans les collections britanniques, des notes, une bibliographie et un index.

\section{AUTEURS}

\section{ÈVE FEUILLEBOIS-PIÉRUNEK}

Université Sorbonne Nouvelle-Paris 3/Mondes iranien et indien, Paris 